\title{
Can institutional investors bias real estate portfolio appraisals? Evidence from the market downturn
}

Article

Accepted Version

Crosby, N., Devaney, S., Lizieri, C. and McAllister, P. (2018) Can institutional investors bias real estate portfolio appraisals? Evidence from the market downturn. Journal of Business Ethics, 147 (3). pp. 651-667. ISSN 1573-0697 doi: https://doi.org/10.1007/s10551-015-2953-1 Available at https://centaur.reading.ac.uk/47878/

It is advisable to refer to the publisher's version if you intend to cite from the work. See Guidance on citing.

To link to this article DOI: http://dx.doi.org/10.1007/s10551-015-2953-1

Publisher: Springer

All outputs in CentAUR are protected by Intellectual Property Rights law, including copyright law. Copyright and IPR is retained by the creators or other copyright holders. Terms and conditions for use of this material are defined in the End User Agreement.

www.reading.ac.uk/centaur 
Central Archive at the University of Reading

Reading's research outputs online 


\title{
Can Institutional Investors Bias Real Estate Portfolio Appraisals? Evidence from the Market Downturn
}

Neil Crosby $^{1}$, Steven Devaney $^{1 *}$, Colin Lizieri $^{2}$ and Patrick McAllister ${ }^{1}$

\section{Henley Business School, University of Reading, UK}

\section{Department of Land Economy, University of Cambridge, UK}

\author{
* Author to whom correspondence should be addressed \\ Real Estate \& Planning, \\ Henley Business School, \\ University of Reading, \\ Whiteknights, \\ Reading, RG6 6UD \\ United Kingdom \\ Tel: +44 (0) 1183786657 \\ Email: s.devaney@henley.reading.ac.uk
}

This is an Accepted Manuscript of an article published by Springer in the Journal of Business Ethics. The final publication is available at Springer via http://dx.doi.org/10.1007/s10551-0152953-1

\section{Acknowledgements}

The authors acknowledge the contribution of Dr Yarim Shamsan, who compiled the data for this study while working as a joint research officer for the University of Reading and Investment Property Databank. 


\section{Can Institutional Investors Bias Real Estate Portfolio Appraisals? Evidence from the Market Downturn}

\section{Abstract}

This paper investigates the extent to which institutional investors may have influenced independent real estate appraisals during the financial crisis. A conceptual model of the determinants of client influence on real estate appraisals is proposed. It is suggested that the extent of clients' ability and willingness to bias appraisal outputs is contingent upon market and regulatory environments (ethical norms and legal and institutional frameworks), the salience of the appraisal(s) to the client, financial incentives for the appraiser to respond to client pressure, organisational culture, the level of moral reasoning of both individual clients and appraisers, client knowledge and the degree of appraisal uncertainty. The potential of client influence to bias ostensibly independent real estate appraisals is examined using the opportunity afforded by the market downturn commencing in 2007 in the UK. During the market turbulence at the end of 2007, the motivations of different types of owners to bias appraisals diverged clearly and temporarily provided a unique opportunity to assess potential appraisal bias. We use appraisalbased performance data for individual real estate assets to test whether there were significant ownership effects on performance during this period. The results support the hypothesis that real estate appraisals in this period reflected the differing needs of clients.

Keywords: Appraisal. Client Influence. Institutional Investors. Performance Measurement. Real Estate. 


\section{Introduction}

Over the last 15 years, a recurring theme from investment markets has been deep concern about the ethical standards of information intermediaries such as rating organisations, auditors and financial analysts. The focus on this paper is on client pressure on appraisers in the commercial real estate investment sector. Many real estate appraisers can tell vivid anecdotes about pressure from clients to adjust their appraisals. Appraisers may alter their ostensibly independent estimates of Market Value in anticipation of clients' adverse reactions. Such moral hazard problems are endemic in many consumer and business services. The examples of the ratings agencies before the sub-prime crisis and of equity analysts and auditing professionals during the equity/dot-com bubble before 2001 are some of the most notorious cases of how the quality of business services can be significantly impaired by a systemic breakdown in ethics. In these cases, the combination of personal and corporate incentives to maintain and generate additional income from clients and incentives for clients themselves to obtain biased advice coupled with limited regulatory oversight proved to be extremely problematic. The experience of appraisals in commercial real estate markets has been much less dramatic. However, it is still widely presumed that, given the existence of similar economic incentives for both clients and service providers (albeit with significant counter-incentives), the commercial real estate appraisal sector is prone to such problems.

This paper investigates the extent to which clients were able to bias real estate appraisals used for investment performance measurement during the downturn in commercial real estate markets that began in the UK during the second half of 2007. While it was an extreme event, the 
associated liquidity and price shock in this period generated anecdotal speculation that different types of institutional real estate investors had incentives, and were attempting, to influence their appraisers in different directions. Specifically, the requirement for open-ended real estate funds to meet high levels of demand for redemptions gave them strong incentives to ensure that their asset valuations were quickly marked (downwards) to market. In contrast, it was suggested that other investors, such as REITs and closed-end funds, had incentives to resist falls in their asset valuations, e.g. to maintain share prices or to comply with banking covenants. This divergence in incentives provides a unique opportunity to observe the extent to which the different motivations of clients led to different appraisal outcomes that, in turn, could be evidence of client influence.

\section{Background and Context}

In public financial asset markets, the price of an asset is usually observable and, hence, the estimation of selling price is not a critical exercise. This is facilitated by the fact that, for any individual company or bond issue, thousands of trades in identical shares or bonds take place frequently and almost instantaneously. In contrast, commercial real estate markets are private and decentralised and the constituent assets are far less frequently traded (Collett et al., 2003). In this context, estimates of the likely selling price act as a proxy for actual prices and are important in guiding market participants. Such estimates are supplied by real estate appraisers and are termed 'Market Value'. However, commercial real estate assets are heterogeneous, with varying location, legal and physical characteristics, which increases the difficulty of accurate estimation. As such, the record of real estate appraisers in regard to appraisal accuracy is varied. Studies are 
difficult to undertake owing to data constraints, but an RICS/Investment Property Databank study of sale prices and preceding real estate appraisals suggests that, in the UK, the average absolute variation from sale price was greater than $10 \%$ in the 12 years to 2011 (RICS/IPD, 2013).

Thus appraisals, as estimates of likely selling price, are subject to variability and it is this variation and lack of precision that makes them easy to criticize. Nonetheless, they are required and commissioned for a number of purposes. A substantial proportion of them are single, transaction-related appraisals in which the appraisal figure can be critical to the completion of the transaction. Appraisals to support secured bank lending decisions fall into this category and have been the subject of scrutiny concerning whether lenders and borrowers or any other stakeholders in the process might want to influence the appraisal outcome (see, for example, Worzala et al., 1998; Levy and Schuck, 1999, 2005). In these cases, pressure was normally applied to increase the value.

However, there is also demand for periodic or repeated appraisals for investment performance measurement and for financial reporting. Listed property companies and REITS in the UK ${ }^{1}$ require them for their accounts and analysts use them to interpret financial ratios and make buy/sell recommendations. Typically, performance measurement appraisals are used to measure the performance of an asset within a fund and also the performance of the fund manager; in many cases, the fund managers' remuneration can be linked to an appraisal-based performance

\footnotetext{
${ }^{1}$ In common with most European property firms, and in contrast to US REITs, UK REITs and listed property companies follow IFRS and must report their real estate assets at fair value, not historic cost.
}

The final publication is available at Springer via http://dx.doi.org/10.1007/s10551-015-2953-1 
metric. When remuneration is linked to investment performance that, in turn, is based on appraisals, there are obvious incentives for fund managers to attempt to bias the outcome. Appraisals are also used to set unit pricing for unlisted commercial real estate funds, such as property unit trusts and unit linked or insurance funds, where bid and ask prices are set on a net asset value basis. As discussed in more detail below, accurate appraisals are particularly crucial to this type of fund manager to enable them to manage the fund fairly between existing, new and departing unit holders. This can be more difficult to achieve in rapidly moving markets, especially when the demand to redeem units is high. In addition to fund performance, the same appraisals can be used to assess whether investment funds or real estate companies that are levered are compliant with maximum loan-to-value ratios.

In mature real estate markets, the requirements and conduct of appraisals are typically regulated by a blend of government legislation and professional institutions. In the UK, the most important professional regulatory body is the Royal Institution of Chartered Surveyors (RICS). They produce guidance on professional standards for real estate appraisal. The use of the RICS guidance is mandatory on Chartered Surveyors, who undertake virtually all regulated external ${ }^{2}$ appraisals in the UK, including performance measurement appraisals. RICS (2014) states that an appraiser must act independently and objectively at all times.

Baum et al. (2000) investigated the appraisal process in the UK. Drawing upon interviews with fund managers and appraisers, they found evidence of client pressure within a process that

\footnotetext{
${ }^{2}$ Appraisals may also be conducted 'in-house' by internal appraisers. This paper is focused on ostensibly independent appraisals provided by external consultants.
}

The final publication is available at Springer via http://dx.doi.org/10.1007/s10551-015-2953-1 
provided fund managers with the means to influence appraisals. This issue was explored by RICS who responded to Baum et al (2000) with a major investigation of appraisal practice in the UK, commissioning a report by the former Chair of the UK Office of Fair Trading, Sir Bryan Carsberg (RICS, 2002). Rather than ban meetings to discuss draft appraisals which were, and still are, ingrained in the appraisal process, the RICS inserted a requirement in their appraisal standards for their members to keep records of such meetings noting that:

\footnotetext{
"A threat to the member's objectivity can arise where the outcome of a valuation is discussed before its completion with either the client or another party with an interest in the valuation. While such discussions are not improper, and indeed may be beneficial to both the member and the client, the member must be alert to the potential influence that such discussions may have on his or her fundamental duty to provide an objective opinion" (RICS, 2014, PS. 2, para 4.10)
}

The Carsberg Report also recognised the notion of beneficial client influence in relation to communication between client and appraiser during the appraisal production process (RICS, 2002: 22). An example of beneficial client influence could be where clients assist the external appraiser by providing additional and better asset or market information that may not have been evident initially owing to the private nature of real estate markets. This provides a justification for client intervention that was accepted by Carsberg. It is also common for clients to check appraisals for errors or omissions. Assuming that information provision by clients is not selective, this process should not lead to systematic bias of appraisal outcomes. However, not all client influence may be benign. Crosby et al. (2010) characterised detrimental client influence as intervention by the client in the appraisal production process in order to bias appraisal outcomes. Whilst most studies have focussed on attempts to 'ramp up' appraisals above appraisers' independent estimates of Market Value, clients may, in some circumstances, have incentives to bias appraisals downwards. 
In the next part of the paper, we outline a conceptual model of the determinants of detrimental client influence in real estate appraisals. It is suggested that the extent of such influence is contingent upon market and regulatory environments (ethical norms and legal and institutional frameworks), the salience of the appraisal(s) to the client, financial incentives for the appraiser to respond to client pressure, the level of moral reasoning of both client and appraiser and the degree of appraisal uncertainty. We then discuss the UK commercial real estate market and the sharp falls in capital values of real estate investments that coincided with the global financial crisis. After this, we introduce the data and econometric models that we use to test whether, all else equal, ownership had a significant effect on asset performance during this period. The paper finishes by reporting the results of our empirical modelling before drawing conclusions.

\section{Literature Review}

Similar to auditors, accountants, equity and rating analysts, commercial real estate appraisers act as information intermediaries. There is a large body of academic research on information intermediaries to suggest that their advice may not always be independent. For equity analysts, much-cited papers by Lin and McNichols (1998) and Michaely and Womack (1999) found that analysts' recommendations were affected by their firm's business relationship with a company. Malmendier and Shantikumar (2005) investigated whether there were misaligned incentives when dealing with uninformed or small investors compared to informed or institutional investors. They found that analysts affiliated to an investment bank made a strategic choice to distort recommendations to small investors, but not the earnings forecasts used by the 
institutional investors. It was concluded that analysts may have felt that the incentives to maintain favourable relationships with existing or potential corporate clients were outweighed by the disincentives of loss of credibility and reputation that could occur with "expert" investors.

Another area of finance where client effects are argued to have influenced outcomes is in the credit rating business. Various explanations for the apparently optimistic ratings of securitisation tranches in light of subsequent downgrading and losses have been offered. These include "rating shopping"; the role of competition and pursuit of market share; and employment impacts from the close relationship between rating agencies and issuers. Furthermore, there was a strong concentration of issuers in asset backed securitisation in the period immediately before the credit crunch. It has been estimated that over $70 \%$ of US MBS issuance was written by just ten firms (Habinek et al., 2012). As a result, client effects may have been pronounced.

There is evidence of rating agencies producing biased ratings. Benmelech and Dlugosh (2009a, 2009b) find that tranches rated by only one firm were more prone to downgrades than tranches rated by more than one firm. Ashcraft et al. (2010) find a similar result. In a similar vein, Griffin and Tang (2011) look at qualitative 'adjustments' to the ratings of CDOs. An adjustment was defined as the difference between the output from the pure quantitative model and the actual rating that was awarded. They found that nearly $85 \%$ of adjustments were positive and that the amount of adjustment at the time of CDO issuance was positively related to future downgrades. Bolton, Freixas and Shapiro's (2012) model of rating agencies' behaviour cited many variables that also exist in the commercial real estate appraisal sector - payment by the 'issuer', limited 
precision, the ability to make adjustments, the presence of reputational concerns and barriers to entry.

In the auditing literature, independence is defined as the absence of collusion between the auditor and the manager of the client firm (Lee and Zhaoyang, 1998). Problems can occur where there is "mutuality of interests" between auditor and client owing mainly to auditor economic dependence and/or the provision of non-auditing services by the auditing firm (see Zhang, 1999; Windsor and Ashkansay, 1995; Zimbelman and Waller, 1999). DeAngelo (1981) first suggested that incumbent auditors could not be perfectly independent from their clients, who are able to impose costs by switching. Empirical research suggests evidence of shifting and contingent influence. For instance, Khurana and Raman (2006) find that higher audit fees are positively associated with the cost of equity. However, studies have also found evidence of counterincentives to mitigate the potential agency costs associated with economic dependence. Reynolds and Francis (2000) and Gaver and Paterson (2007) found that, consistent with potential large costs of lawsuits, the Big Five US audit firms tend to be more conservative in auditing larger firms.

In the real estate literature, there is an established body of work that has identified different types of influence (coercive, covert, reward, information) on different categories of appraisal (transactional, periodic) at different stages of the process (instruction, information collection, calculation, reporting, etc.). The vast majority of existing research has been either quasiexperimental (see Kinnard, et al., 1997; Diaz III and Hansz, 1997; Hansz and Diaz III, 2001; Hansz, 2004; Amidu and Aluko, 2007a; Amidu et al., 2008) or interview and/or survey-based 
(see Smolen and Hambleton, 1997; Worzala et al., 1998; Gallimore and Wolverton, 2000; Yu, 2002; McAllister et al., 2003; Crosby et al., 2004; Levy and Schuck, 2005; Amidu and Aluko, 2007b; Nwuba et al., 2015).

Given the reputational and possibly criminal issues involved, it is clear that there may be problems of self-report bias in interview and questionnaire-based studies. Hence, while this existing body of research provides indications of the possible drivers and appraiser responses to pressure from clients, it is relatively undeveloped compared to the work on auditor independence. There remains considerable scope for research on how detrimental client influence varies with the purpose of the appraisal, client, appraiser and asset and market conditions. It is possible that in interviews or questionnaire responses, appraisers may anchor on atypical or one-off incidents. There is still little evidence on the extent to which such pressure tends to be sporadic or endemic and temporary or permanent.

A stylized fact that emerges from this body of work is that clients attempt to influence appraisal outcomes and that appraisers are likely to respond to client pressure. However, two studies have special significance for this paper. Although primarily interview based, the study by McAllister et al. (2003) found that periodic monthly appraisals were treated somewhat differently from annual or even quarterly revaluations. Appraisers admitted to not giving monthly appraisals the same degree of attention as annual or quarterly appraisals, while analysis of UK data on periodic appraisals found that the majority remained unchanged from month to month. McAllister et al. (2003) also identified issues with market state and appraisers' ability to identify price changes in markets in some sort of crisis. Real estate markets had a major reduction in trading in the period 
of the Russian Debt Crisis. Appraisers reacted by keeping over $80 \%$ of monthly appraisals unchanged in October 1998 against a longer term average of 69\%. This gives some indication of what might have been expected to happen in the 2007 crisis. McAllister et al. (2003) also identified the process by which appraisals were negotiated between client and appraiser at a draft stage, providing the means to influence them.

Meanwhile, Crosby et al. (2010) used the 2007/08 financial crisis to identify whether type of owner had an effect on the movement of real estate values in the UK during the downturn in a rare quantitative study of client influence. They hypothesised that certain types of owners would have an interest in moving appraisals up in relative terms while others would have an interest in moving them down even further. They found that, in the aftermath of a run on open ended real estate funds in the second half of 2007 (in particular, the last quarter of 2007 when redemptions peaked at over $£ 1.6$ billion) valuations of their portfolios fell more than those of portfolios owned by pension funds and property companies. This was despite the fact that these open ended funds were appraised monthly, where, according to McAllister et al. (2003), most appraisals do not move month to month and the number of appraisals not moving increases when markets are in crisis. However, the Crosby et al. (2010) study could not obtain access to individual asset data, so could only undertake analysis at a highly aggregated, fund type level leading to concerns that the results might be affected by differential quality of portfolios between investor types. The present paper builds on this earlier work by developing the conceptual framework and by examining individual asset appraisals during the UK commercial real estate crash from 2007 to 2009. 


\section{Client Influence: A Conceptual Model}

Levy and Schuck (1999) outlined a preliminary framework to describe the key variables that might determine the extent of client influence or bias on real estate appraisals. While no explicit connection was made, their framework echoed (albeit less formally) Trevino's (1986) interactionist model of ethical factors in organisational decision-making. Levy and Schuck's model identified four main categories of factors (individual and organisational characteristics, external characteristics, client characteristics and service characteristics) that determine the amount and type of power and, therefore, influence. A range of characteristics were outlined in each category. The conceptual model presented here in Figure 1 represents the extent of detrimental client influence as a product of the balance of effects from a range of internal and external variables on both clients and appraisals. It was produced through an iterative process informed by the authors' tacit and explicit knowledge obtained from their current and previous research in this area.

\section{INSERT FIGURE 1 ABOUT HERE}

From the client perspective, the salience of the appraisal is a key situational factor determining the extent of their motivation to attempt to influence the appraisal. The relative importance of appraisals to clients can vary substantially among clients and over time. In certain circumstances, 'adverse' appraisals can result in aborted transactions, lower than expected remuneration and fund insolvency. In contrast, for many corporate organisations, while their real estate holdings are a key factor of production, the value of the real estate can be of limited 
importance to their financial performance. The incentives and counterincentives for clients to apply pressure on appraisers to deviate from their independent estimates of value are contingent on the relative costs and benefits of applying such pressure. In addition, the degree of client knowledge regarding the asset and the appraisal process will affect their ability to contest appraisals.

The incentives and counterincentives for the individual appraiser to respond to pressure from clients and to deviate from their independent estimates of value are, in turn, contingent on the relative costs and benefits of yielding to client pressure. An over-arching agency problem is that the appraiser (and/or their firm) can have a conflict of interest between their own self-interest and a professional obligation to provide independent appraisals. There can be a complex range of incentives and counterincentives for appraisers who are trying to balance losses due to reputational damage and potential litigation risk against revenue losses caused by loss of client.

Situational drivers, such as economic dependence, are refracted through individual fund managers (clients) and appraisers. Internal or dispositional factors then become determinants of the outcome of the 'negotiation' process. In the auditing literature, the main focus has been on variations in the level of moral reasoning among individuals (see Trevino, 1986). In an auditing context, Windsor and Ashkansay (1995) identify three categories of individual - autonomous, pragmatic and accommodating - who, it is proposed, respond in different ways to client pressure. In addition, individual behaviour will be affected by the core values of their employer's organisational culture (see Schein, 1984). In turn, individuals and firms exist within a wider 
business culture and it is generally acknowledged that different markets and cultures have different rules and expectations regarding ethical standards (Ahmed et al., 2003).

A key enabler of client pressure and influence is the intrinsic uncertainty in real estate appraisals. For most commercial real estate assets, the appraisal process relies upon the analysis of historical transactions. It is widely recognised that there are a number of inherent limitations. First, the reliability of a transaction price signal decays in proportion to the quantity of exogenous market movements. Put simply, the more the market changes in the period between the transaction and the appraisal, the less reliable will be evidence from the transaction. Second, transactions are 'noisy' due to the individual characteristics of assets, buyers and sellers (as in Quan and Quigley, 1991). Whilst the first problem is unavoidable, the 'signal to noise' problem is mitigated in active markets which generate substantial price information. However, thin trading in real estate markets typically results in poor information flows, which vary over time and among market segments.

In deteriorating or weak market conditions, these inherent sources of appraisal uncertainty can shift from a chronic to an acute state. In a downturn, trading volumes can fall dramatically and appraisers can find themselves with little transaction evidence upon which to estimate the size of the change in values that has occurred. However, whatever the market state, there is scope for a range of interpretations by market participants of a pricing signal. This is because, relative to the asset being appraised, the prior transaction took place in different market conditions, involved a different asset and was generated by the interaction of unique buyers and sellers. These factors 
heighten appraisal uncertainty and appraisal variation ${ }^{3}$ and, most significantly in this context, provide a valid basis for appraisals to be contested. This has been explicitly acknowledged in professional standards where it is stated that appraisals undertaken in the wake of or during

"unforeseen financial, macro-economic, legal, political or even natural events...there may be a reduced level of certainty that can be attached to a valuation, due to inconsistent, or an absence of, empirical data, or the valuer being faced with an unprecedented set of circumstances on which to base a judgment. In such situations, demands placed on the valuer can be unusually testing. Although valuers should remain able to make a judgment, it is important that the context of that judgment is clearly expressed." (RICS, 2014, VPGA 9, para 2.6)

As in the capital markets and the real economy, the fall in real estate values across 2007 and 2008 can be characterised as an extreme event for the UK commercial real estate market. For a number of clients, the consequences of the downturn threatened their economic existence and increased incentives for fund managers to apply pressure to appraisers and for appraisers to respond to such pressures.

\section{The Market Context}

Since 2002, the UK commercial real estate market has experienced a major boom and slump, followed by recovery. Between February 2002 and June 2007, the IPD UK monthly capital growth index ${ }^{4}$ rose for 65 consecutive months. Over that period, capital values increased by $53 \%, 8.2 \%$ per annum in nominal terms and $4.6 \%$ per annum in real terms. Capital values then started to fall in July 2007 and by July 2009 the IPD monthly index had fallen for 25 consecutive

\footnotetext{
${ }^{3}$ That is disagreement between appraisers on the value of the same property.

${ }^{4}$ IPD is part of MSCI and is the leading provider of real estate investment performance benchmarks in the UK and in many other international real estate markets.
}

The final publication is available at Springer via http://dx.doi.org/10.1007/s10551-015-2953-1 
months. Capital values fell by approximately $12 \%$ in the second half of 2007 and by more than a third from their peak in June 2007 to the end of 2008, with the steepest falls during Q4 2007 and Q4 2008. At the same time, appraisers were faced with greater uncertainty since, as a consequence of the falling markets, transaction volumes fell markedly.

\section{INSERT FIGURE 2 ABOUT HERE}

The rapid change in market conditions in 2007 caused a range of problems for real estate investors and fund managers. Crucially, the nature and severity of the problems varied across client types. Open ended funds faced particular difficulties, especially unit trusts with defined redemption policies based on the last published net asset value (NAV). Redemptions rose from around $£ 300$ million in Quarter 12007 to $£ 600$ million in Quarter 2, to over $£ 900$ million in the three months to September 2007 before peaking in Quarter 42007 at $£ 1.65$ billion. In 2008 redemptions fell back but still averaged around $£ 750$ million per quarter. It was only in Quarter 3, 2009 that redemptions fell back to their pre-financial crisis levels (Crosby et al., 2010).

For those open-ended funds without strong cash reserves, redemptions could only be made through asset sales in a market that was experiencing sharp falls in values and liquidity. Unless asset values were marked to market accurately, exiting investors would receive payments above liquidation value to the detriment of remaining investors. Faced with such problems, most openended funds had few options. Many could not 'freeze' redemptions and seeking new capital was not feasible. Whilst they could widen bid-ask spreads, a key priority was to ensure that their appraisal-based unit prices were as accurate as possible. It is notable that the most of the open

criticism of appraisers reported in practitioner journals was from open ended fund managers The final publication is available at Springer via http://dx.doi.org/10.1007/s10551-015-2953-1 
complaining that appraisals had not fallen quickly enough (for examples, see EG Capital, 2008 and IPE Real Estate, 2009).

In contrast, other types of owner faced different pressures. For closed-end funds, property companies and Real Estate Investment Trusts (REITs) that were leveraged, sharp falls in appraised capital values created the risk of breaching loan-to-value covenants with their lenders. Finally, fund managers whose remuneration included a performance component - the beating of an absolute or relative benchmark target - again had incentives to resist sharp downward movements in appraisals.

Drawing upon the existing research outlined above, our underlying analytical framework is that there is regular negotiation between clients and appraisers about periodic appraisals, with a complex range of incentives and counter-incentives varying among clients and appraisers to bias appraisals. However, the primary effect of client influence in the specific set of market conditions investigated is expected to be on the timing of the change in appraisal rather than the extent of it. Essentially, when there is a noisy price signal suggesting a shift in values, appraisers and clients have different propensities to update appraisals to incorporate that signal owing to differences in prior beliefs and incentives. Clients who believe that there is a high probability that the signal is correct or have incentives to accept its accuracy and are more likely to pressure their appraisers to incorporate it into their appraisals. On the other hand, clients who believe that there is a low probability that the signal is correct or incentives to doubt or reject its accuracy are more likely to pressure their appraisers not to incorporate it into their appraisals. However, if the 
signal is proven to be reliable, it is expected that the latter group will accept eventually that prices have changed, producing a Bayesian-style convergence to agreement.

This suggests that there should be little long term difference in performance between owner types due to owner influence on appraisals. Instead, it is the timing of recorded performance that will differ. For example, taking a highly simplified scenario, assume that a noisy price signal arrives suggesting that values have risen by $10 \%$. The appraiser is uncertain about whether to factor this signal into their appraisals. In Period 0, Owner A believes that there is a high probability (or has incentives to believe) that this signal is correct and pressures the appraiser to incorporate the information. Owner B, in contrast, believes that there is a low probability that this signal is correct (or has incentives to reject the new information) and pressures the appraiser not to incorporate the information. As a result, Owner A has a better performance than Owner B in Period 0. However, in the next period (Period 1), new information arrives that supports the beliefs of Owner A and Owner B now has to accept that there has been a pricing shift. All else equal, in Period 1 Owner B now achieves a better performance than Owner A, as the appraisals for their assets adjust upwards. Thus, over the two periods, their performance should be identical despite short-term client influence.

The period of the global financial crisis created the context for a natural experiment to test client influences on appraisals. During this period, the incentives for different types of clients to bias appraisals diverged dramatically and temporarily. This generated strong prior expectations about the way that appraisals of assets owned by different owners would behave and anecdotal 
evidence suggesting that this type of client pressure was occurring. The data and modelling strategy used to test these expectations are described in the next two sections.

\section{Data}

The data used in this study relate to individual assets for which information is recorded in the databases of IPD. This information is supplied by major real estate investors for the purpose of receiving performance measurement and benchmarking services. These include insurance companies, pension funds, open-ended funds, closed-end funds and REITs. The coverage by IPD of institutional investment in UK real estate is good, but not complete. Recent estimates suggest that their indexes currently cover around $40 \%$ of the investment market in UK real estate (see Mitchell, 2014; Teuben and Clacy-Jones, 2015). One issue is that their database focuses on domestic investors only and a growing proportion of UK investment-grade real estate is now held by overseas investors, particularly in the case of Central London (see Lizieri et al., 2011). There is also little or no coverage of private property companies or private investors.

The study draws, in particular, on appraisals supplied for properties that are part of the IPD UK Quarterly Property Index. As at December 2014, this comprised 9,747 properties held by 229 separate funds and with a total value of more than $£ 140$ billion (IPD, 2015). Although IPD produces an index based on assets appraised at a monthly frequency, the quarterly index has a much greater number of assets and a greater mix of owners for testing the hypotheses put forward in this study. 
The dataset consisted of observations for 10,979 individual commercial properties that produced capital return figures for at least one quarter during Q3 2007 to Q2 2009. The study period was defined with reference to market indices, discussed earlier, that identify the end of the UK commercial real estate boom as occurring in 2007 and the trough in values being reached in Q2 2009. Therefore, the dataset spans the entire period of prolonged decline in capital values in this market. The sample primarily consists of office, retail and industrial buildings, reflecting the nature of the UK real estate investment market where residential properties do not play a major part in institutional portfolios. Panel data were available on the capital value, rental value, capital expenditure and yield (capitalization rate) of each property and descriptive fields for property type, region and tenure were also present. $^{5}$

Essential fields for this study are information on ownership and measures of how values have changed. Details of identity, address and specific owner were not incorporated in the dataset to preserve confidentiality, but type of owner, as defined by IPD, was supplied. The types are fairly broad, comprising insurance company, pension fund, unit-linked fund, listed property company or REIT, open-ended fund, closed-end fund, and other. Additional information about each owner such as size or leverage were not provided to avoid inadvertent identification, but this represents a limitation because, within owner types, pressures and motives for influencing appraisals could vary with these characteristics. Similarly, details about the identity and nature of the companies producing appraisals were not available.

\footnotetext{
5 The IPD databases also contain information on leasing and building vacancy, but these data were not made available for the period studied here.
}

The final publication is available at Springer via http://dx.doi.org/10.1007/s10551-015-2953-1 
The number of observations in each quarter by type of owner is shown in Table 1. The sample reduces between the start and end of the period as assets are sold or when funds leave the IPD service. Open-ended funds are the largest group in terms of the number of properties. ${ }^{6}$ The second largest type is unit linked funds. These are funds that typically attract money from defined contribution pension plans and from which money may be withdrawn and redirected into other types of investment such as equities or bonds. Thus, they share important characteristics with open-ended funds. Self-administered pension funds are the third largest group while insurance companies refers to assets held in the life funds of such companies rather than total assets under management, which may include assets in unit linked or open ended funds that they administer.

\section{INSERT TABLE 1 ABOUT HERE}

The capital growth of each asset from quarter to quarter will be driven largely by changes to the capital value, as judged by the appraiser, over that interval. However, IPD also adjust for any capital expenditure in that period so that reported capital growth approximates the effect of market conditions on the value of that asset during the period. The formula used by IPD (2014) to calculate a single period capital return is as follows:

$$
\mathrm{CR}_{\mathrm{t}}=\left(\frac{\mathrm{CV}_{\mathrm{t}}-\mathrm{CV}_{\mathrm{t}-1}-\mathrm{CX}_{\mathrm{t}}+\mathrm{CI}_{\mathrm{t}}}{\mathrm{CV}_{\mathrm{t}-1}+\mathrm{CX}_{\mathrm{t}}}\right) \times 100
$$

\footnotetext{
${ }^{6}$ They are also the largest owner group on a value-weighted basis. When values are taken into account, listed companies and REITs are more important and unit-linked funds are less important.
}

The final publication is available at Springer via http://dx.doi.org/10.1007/s10551-015-2953-1 
where $\mathrm{CR}$ is the capital return during quarter $\mathrm{t}, \mathrm{CV}$ is the capital value at the end of a quarter, $\mathrm{CX}$ relates to capital expenditure in that quarter and CI relates to capital receipts received over that quarter.

Quarterly rental value growth and yield impact figures were also available in the dataset. The former captures the change in rental value from period to period. Rental value growth may not result in a change to current rental income, as the actual rent is usually fixed by the terms of the lease contracts in place. However, it represents a potential source of future change in income and so influences capital value estimates. Yield impact measures the effect on capital value of changes in an asset's equivalent yield. ${ }^{7}$ For example, if the yield for a property moved from $6 \%$ to $7 \%$, the impact on its capital value would be negative (capital growth would be $-14.29 \%$ in this example). More formally, it is computed by IPD as:

$$
\mathrm{YI}_{\mathrm{t}}=\left(\frac{\mathrm{Y}_{\mathrm{t}-1}}{\mathrm{Y}_{\mathrm{t}}}-1\right) \times 100
$$

Where YI refers to yield impact and Y refers to the yield level at time $\mathrm{t}$ or $\mathrm{t}-1$. The reason for including these additional measures is to better understand the means by which appraisals might be adjusted under the influence of client pressure. It may be that estimates of rental value and the yields applied to those estimates are influenced or that one is more likely to be influenced

\footnotetext{
${ }^{7}$ Equivalent yield is a form of capitalisation rate that is commonly used in the UK and which reflects current rental income and a future reversion to the current level of rental value. It essentially acts in the same way as an income multiplier. It is a key assumption in the appraisal process and is usually based on analysis of transactions involving comparable assets. A change in yield typically reflects a change in the pricing of an asset as market conditions change.
}

The final publication is available at Springer via http://dx.doi.org/10.1007/s10551-015-2953-1 
than the other. It is expected that changes to appraisals are easier to achieve through yield adjustments. As a high proportion of rent tends to be contractually fixed, implausible shifts to appraised rental values would often be required to produce decrease in capital value of 5\%-10\%. However, such changes in the appraisal could be achieved by changing the yield from, say, $4.5 \%$ to $4.75 \%$ or $5.00 \%$. Furthermore, rental transactions are typically more frequent and so supporting evidence for the rental part of the appraisal may be greater in many cases.

\section{The Econometric Model}

Hedonic regression modeling is a standard methodology for examining price or value determinants in real estate research. We use this method in our study primarily to isolate the effect of type of owner. The quintessential log-linear hedonic model takes the following form:

$\ln C V_{i}=\alpha+\beta x_{i}+\phi Z_{i}+\varepsilon_{i}$

where $C V_{i}$ is the capital value for a given building (often expressed on a per square metre basis), $x_{i}$ is a vector of several explanatory locational, lease and physical characteristics, $Z_{i}$ is a vector of time-related variables and $\beta$ and $\varphi$ are the respective vectors of parameters to be estimated. $\varepsilon_{l}$ is a random error and stochastic disturbance term that is expected to take the form of a normal distribution with a mean of zero and a variance of $\sigma_{e}^{2}$. The hedonic weights assigned to each variable are equivalent to this characteristic's overall contribution to the value or price (Rosen, 1974). An alternative specification, appropriate for the tests performed in this paper would be to model not the capital value itself but the periodic change in capital value: 
$\delta \mathrm{CV}_{\mathrm{i}}=\alpha+\beta \mathrm{x}_{\mathrm{i}}+\phi \mathrm{Z}_{\mathrm{i}}+\varepsilon_{\mathrm{i}}$

A summary specification of the econometric model of capital growth rates is as follows:

$$
\begin{aligned}
& \text { CapGrowth }_{i}=\alpha+\beta_{1} \sum_{n=1}^{N} \text { PASCapGr } r_{i}+\beta_{2} \sum_{n=1}^{N} \text { InCapVal }+\beta_{3} \sum_{n=1}^{N} \text { ExcessYield }+ \\
& \beta_{4} \sum_{n=1}^{N} \text { Sold }_{i+1}+\beta_{5} \sum_{n=1}^{N} \text { OwnerDum }+\varepsilon_{i}
\end{aligned}
$$

CapGrowth is the dependent variable and represents the percentage change in the property's value, computed in the manner shown by equation (1). Meanwhile, PASCapGr represents the percentage change in the capital growth index in that quarter for the IPD Portfolio Analysis Service (PAS) segment to which each asset belongs. These segments distinguish different parts of the UK real estate investment market at a broad level. For example, retail assets are classified into four segments based on type and geography, office assets into four segments based on geography and industrial assets into two segments based on geography. Hence, this variable should capture general trends in the part of the real estate market that is relevant to each asset and it is expected that this variable will be the most important determinant of an individual asset's capital growth in any given quarter.

InCapVal represents the capital value of the property as at the end of Q2 2007. This is included to control for the effects of lot size on value, as higher value assets may exhibit different performance trends to lower value assets. ExcessYield represents the difference between the 
equivalent yield of the property and the equivalent yield reported for its PAS segment as at the end of Q2 2007. This is a portmanteau variable that attempts to control for unobserved factors that create differences in the quality of assets due to, inter alia, variations in unexpired lease terms, tenant covenant strength and age of the building. A low yield relative to the segment average may indicate an asset that is considered to be prime in nature and such assets may exhibit different performance to those with higher yields in that segment. Both of these variables are kept at their Q2 2007 values in all models so that they are independent of subsequent changes in capital growth.

Sold is a dummy variable that is set to one where an asset has been sold in the following quarter. Given the stylised fact that real estate appraisals lag actual market prices (see Geltner et al., 2003), it is expected that, for properties that are in the process of being sold and where the price is agreed, the appraisal will be lower (higher) in a falling (rising) market than it otherwise would be, as knowledge of the price is reflected in the estimate of value. Hence, the expected sign of the coefficient should vary with market conditions. Finally, OwnerDum represents a set of dummy variables that are set to one where a property is held by an owner of that particular type and zero otherwise. As noted earlier, there are seven categories of owner: insurance company, pension fund, unit-linked fund, listed property company or REIT, open-ended fund, closed-end fund, and other. The expected coefficient is dependent upon which category is omitted and the quarter in which the model is estimated. We use insurance companies as the hold-out category since they have tended to track the IPD index most closely. ${ }^{8}$ We focus particularly on the fourth

\footnotetext{
${ }^{8}$ This was determined by comparing the tracking error for the aggregate performance of all assets held by each owner type over the period Q2 2007 to Q2 2009.
}

The final publication is available at Springer via http://dx.doi.org/10.1007/s10551-015-2953-1 
quarter of 2007 as this is the period when the conflicting motivations of different types of owners to bias appraisals were reported.

We analyse cross-sectional variations in capital growth between individual properties for each quarter in the period Q3 2007 to Q2 2009. Various functional forms for the models were tested and a standard least squares regression appeared most satisfactory. However, we detect heteroskedasticity, so robust standard errors are used where the assumption of independence in errors has been relaxed in regard to assets owned by the same fund. This is because assets in the same fund may be subject to fund-specific factors that are unobserved and distinct from a general owner-type effect. We also estimate models using either rental value growth or yield impact as the dependent variable given their role in shaping capital growth. Note that these models adopt the same specification to equation (5) except for the different dependent variable and that the PAS variable is amended to rental value growth or yield impact, as appropriate.

In examining the capital growth, rental value growth, equivalent yield and yield impact statistics, it was evident that there were a small number of extreme values or outliers, particularly in the positive tail. We considered excluding these, but had no a priori basis for so doing. Instead, we applied a Winsorizing process to the variables at the $0.5 \%$ and $99.5 \%$ tails. The results from the Winsorized models generally outperformed the untransformed models, based on AIC and Bayesian information criteria, although there were no major shifts in the variable coefficients in terms of either sign or magnitude. We tested for multi-collinearity examining correlations between independent variables and by examining variance inflation factors: no problems requiring model adjustment were encountered. 


\section{Results}

Table 2 shows the output of the models for the particular quarter of interest, Q4 2007, when values fell steeply and redemption pressures on open-ended funds were at their greatest. The table shows results for models of capital growth as well as rental growth and yield impact, the latter being that element of capital growth resulting from yield change. Meanwhile, the results for each quarter starting at the third quarter of 2007 and ending in the second quarter of 2009 are reported in the Appendix Tables A1-A3. As is common in cross-sectional studies of return rates, the $\mathrm{R}^{2}$ is comparatively low in each case, though, interestingly, the explanatory power improves substantially for Q4 2007 compared to other quarters. However, the F-statistics indicate that the models are highly significant in all cases, as are the control variables.

\section{INSERT TABLE 2 ABOUT HERE}

Focusing first on capital growth, Table 2 and Table A1 shows that segment capital return was, as expected, a highly significant determinant of asset capital growth rates. Referring to Table A1, for most of the period, there is a negative relationship between lot size and capital return. Higher value assets appear to have had worse performance than lower value assets after controlling for segment returns. Our excess yield variable is also statistically significant in most quarters. However, the relationship between capital growth and yields is often non-linear and we use a spline to capture variations in behaviour - with yields that are high relative to their segment

being captured by one variable and yields that are low relative to their segment captured by 
another. ${ }^{9}$ For the first six quarters, the sign on excess equivalent yield for assets with higher than average yields is positive. This suggests that the capital values of higher yielding (lower quality) buildings fell less quickly than those of lower yielding (higher quality) buildings. However, in the last five quarters of the period, a negative coefficient where yields are below average suggests that, in these quarters, lower yielding buildings fell less quickly than their counterparts. There are also three quarters where both effects are in evidence. Use of the spline helps to capture this complex relationship with the control variable.

In Table 2 it is apparent that, in the market turmoil towards the end of 2007, assets that were sold in the next quarter had lower capital growth than unsold properties. This is in line with the expectation that actual prices would be lower than appraisal estimates in a period of falling values and that the appraisals of assets being sold would reflect information about these lower prices. In Table A1, it can be seen that the opposite effect is evident in the final quarter of our period, Q2 2009, which was the last quarter before values started to rise again. Both of these results are consistent with the stylized fact that appraisals tend to lag actual prices (see Geltner et al., 2003 and Fisher et al., 2003).

Turning to the impact of fund type on capital returns, we find that, for the final quarter of 2007 , the results are in line with prior expectations. There are some statistically significant ownership effects in other quarters, but, unlike for the final quarter of 2007, we have no strong a priori expectations about the timing and direction of such effects. The results in Table 2 suggest that,

\footnotetext{
${ }^{9}$ These are continuous variables that take either the value of the excess yield where this is above (below) the segment average and zero otherwise.
}

The final publication is available at Springer via http://dx.doi.org/10.1007/s10551-015-2953-1 
compared to ownership by an insurance company, ownership by a pension fund had no statistically significant effect on capital returns. Meanwhile, the coefficient for listed REITs and property companies has the expected positive sign, but is not statistically significant. In other words, we cannot reject the possibility that movements in appraisals were the same for these three groups of investors after controlling for factors such as segment, asset size and yield.

In contrast, compared to ownership by an insurance company, ownership by a closed-end fund had a statistically significant and positive effect on capital returns in the final quarter of 2007. This is consistent with anecdotal reports of the problems that such closed-end funds were having in complying with minimum loan-to-value lending covenants. Indeed, the effect of closed-end fund ownership is particularly striking. With controls for segment type and asset quality, assets owned by closed-end funds recorded falls in value of approximately $2 \%$ less in the final quarter of 2007 than assets owned by insurance companies. For open-ended funds and unit-linked fund, the ownership effects are the opposite. Consistent with anecdotal reports that these investment vehicles were concerned about appraisals failing to respond quickly to deteriorating market conditions, assets owned by open-ended funds and unit-linked funds had lower capital returns than the hold-out category. The coefficients concerned are statistically significant and suggest that, all else equal, their assets recorded falls in value of approximately $1 \%$ more than assets owned by insurance companies in the final quarter of 2007.

Table 2 also includes the results of models where rental value growth and the yield impact are the dependent variables. It is expected that downward value adjustments attributable to owner type would occur through influencing the yield rather than the rental values. Once again, the 
results are consistent with those expectations. There are no statistically significant ownership effects on rental value growth. In contrast, the results for yield impact are similar to the findings for capital return. For open-ended and unit-linked funds, the impact is both statistically significant and negative, suggesting that yield adjustments for properties held by these funds were different to those where insurance companies were the owners, even after controls for segment, asset size and yield level are put in place. Meanwhile, for closed ended funds, the ownership effect is significant and positive.

Finally, for ease of reference, we summarise in Table 3 the instances where movements that are associated with owner type were found to be statistically significant. We focus on unit-linked funds, open-ended funds and closed-end funds as those groups with perhaps the clearest motives for client influence as well as the clearest findings. As discussed, the results in Q4 2007 fit our expectations, but we do not subsequently observe any counter-adjustments to produce the longrun convergence suggested earlier in the paper. However, it could be that continued economic uncertainty and new events confound observation of such a process or that such readjustments are more gradual and are not detected by our models.

\section{INSERT TABLE 3 ABOUT HERE}

\section{Conclusion}

Real estate appraisals are of key importance to the operation of commercial real estate investment markets. They are used in performance measurement, financial reporting, monitoring 
of loan covenants and the unit pricing of pooled vehicles inter alia. There is a well-established body of empirical evidence to suggest that the clients often have the means (domain and market knowledge, intrinsic appraisal uncertainty), motives (remuneration, loan covenants, fund redemption obligations) and opportunities (draft valuation meetings and other forms of client consultation) to bias appraisals. In turn, appraisers often have the means (intrinsic appraisal uncertainty), motive (economic dependence) and opportunities to bias their appraisals in response to or in anticipation of client pressure. However, the extent of such influence is likely to be contingent. Key variables will be the incentives and counterincentives for clients and appraisers to exert or respond to pressure, individual moral reasoning, the organisation and broader business culture, the strength of the regulatory regime, market conditions and the extent of intrinsic appraisal uncertainty.

The potential of client influence to bias ostensibly independent real estate appraisals is examined using the unique opportunity afforded by the market downturn commencing in 2007 in the UK. This forms a natural experiment in that the motivations of different types of owners to bias appraisals diverged clearly and temporarily. In a period when transaction evidence about the extent of changes in market prices was difficult to obtain, there was what came to be labelled as abnormal uncertainty about the extent of the shift in market conditions and prices. Open-ended funds, faced with redemption pressures, had an interest in ensuring that appraisals responded quickly to rapidly deteriorating market conditions. In contrast, often heavily levered closed-end funds with loan-to-value covenant issues had an interest in a 'wait and see' approach, an approach that had been identified with the much more minor Russian Debt crisis, resulting in few monthly valuation movements as identified in McAllister et al. (2003). 
The results presented here are consistent with the idea that the appraisals in this period reflected the differing needs of clients and strengthen the aggregate level data analysis of Crosby et al. (2010). Controlling for asset characteristics and market segment, there appear to be statistically and economically significant client effects. In the specific quarter (Q4 2007) in which there was substantial market gossip about the conflicting pressures on appraisers to adjust (or not) their appraisals, we find that asset values fell more quickly for types of funds with incentives to ensure that their appraisals quickly reflected deteriorating market conditions. In turn, the appraised values of funds with incentives to ensure that those values did not fall tended to achieve higher capital returns than other investors in our sample. The results from the current study reflect a specific set of circumstances which are consistent with the general framework proposed in our conceptual model. The key variable in these specific circumstances was appraisal salience. The results were consistent with variations in appraisal salience (in this case, incentivising different client types to apply pressure in different directions) affecting the appraisal outcomes.

It is challenging to assess whether the results represent relatively strong but unique client influence effects in turbulent market conditions or endemic client behaviour. In addition, it can be difficult to generalise about the pressures and incentives on owners and/or proxy owners such as fund managers. Such pressures and incentives will vary with market conditions and the timing of appraisals. There is also heterogeneity of circumstances such as size, gearing and remuneration models within, as well as between, owner categories. For example, open-ended fund managers may have had conflicting pressures and incentives to meet redemption requirements, comply with loan covenants and meet bonus-related targets. Furthermore, the 
attributes of appraisers (firm and individual) could be important in their ability to withstand such pressures. The absence of further details about owners and appraisers represents a limitation in our findings that future research may be able to address.

However, given the moral and professional disapproval associated with unethical behaviour in business, in addition to potential loss of employment or even criminal prosecution, unethical practices may not be recorded in field studies. Yet should appraisal bias be a surprise when real estate appraisals intrinsically are subject to an element of subjectivity and uncertainty, when appraisers are to some degree economically dependent on their clients and when their clients can have incentives, power and knowledge to bias appraisals? The quality of governance of the appraisal process is at the core of this issue. The UK is one of the most mature and transparent commercial real estate markets in which the behaviour of appraisers is closely monitored by professional bodies. In less mature and transparent real estate markets, where the appraisal profession is often not so well-developed, we suggest that it is more likely that appraisals could be biased by undesirable and potentially systematic client influence. Consequently, this raises wider concerns about the quality of real estate performance measures and other financial information that is appraisal based.

\section{Appendix}

INSERT TABLES A1-A3 HERE

The final publication is available at Springer via http://dx.doi.org/10.1007/s10551-015-2953-1 


\section{References}

Ahmed, K., Chung, K. and Eichenseher, J. (2003), Business Students' Perceptions of Ethical and Moral Judgement: A Cross-Cultural Study, Journal of Business Ethics, 43 (1-2): 89-102.

Amidu, A. and Aluko, B. T. (2007a), Client influence in residential property valuations: an empirical study, Property Management, 25 (5): 447-461.

Amidu, A. and Aluko, B. (2007b), Client influence on valuation: Perceptual analysis of the driving factors, International Journal of Strategic Property Management, 11 (2): 77-89.

Amidu, A., Aluko, B and Hansz, J. (2008), Client feedback pressure and the role of real surveyors and valuers, Journal of Property Research, 25 (2): 89-106.

Ashcraft, A., Goldsmith-Pinkham, P. and Vickery, J. (2010), MBS Ratings and the Mortgage Credit Boom, Federal Reserve Bank of New York, Staff Report No. 449.

Baum, A., Crosby, N., Gallimore, P. Gray, A. and McAllister, P. (2000), The influence of valuers and valuations on the workings on the commercial property market, Report for the Education Trusts of IPF, RICS and Jones Lang LaSalle.

Benmelech, E. and Dlugosz, J. (2009a), The Alchemy of CDO Credit Ratings, Journal of Monetary Economics, 56 (5): 617-634.

Benmelech, E. and Dlugosz, J. (2009b), The Credit Rating Crisis, NBER Working Paper 15045

Bolton, P., Freixas, X. and Shapiro, J. (2012), The Credit Rating Game, Journal of Finance, 67 (1): 85-112.

Collett, D., Lizieri, C. and Ward, C. (2003), Timing and the Holding Periods of Institutional Real Estate. Real Estate Economics, 31 (2): 205-222.

The final publication is available at Springer via http://dx.doi.org/10.1007/s10551-015-2953-1 
Crosby, N., Hughes, C. and Murdoch, J. (2004), Influences on secured lending property valuations in the UK, Working Papers in Real Estate \& Planning 14/04, University of Reading.

Crosby, N., Lizieri, C. and McAllister, P. (2010), Means, Motive and Opportunity: Disentangling the Effects of Client Influence of Periodic Performance Measurement Appraisals, Journal of Property Research, 27 (2): 181-201.

DeAngelo, L. E. (1981), Auditor Size and Audit Quality. Journal of Accounting and Economics, 3 (3): 183-199.

Diaz III, J. and Hansz, J. A. (1997), How valuers use the value opinions of others. Journal of Property Valuation and Investment, 15 (3): 256-260.

EG Capital. (2008), Fund managers question their values as liquidity crisis bites. EG Capital, December, 14-16.

Fisher, J., Gatzlaff, D., Geltner, D. and Haurin, D. (2003), Controlling for the impact of variable liquidity in commercial real estate price indices. Real Estate Economics, 31 (2): 269-303.

Gallimore, P. and Wolverton, M. (2000), The objective in valuation: a study of the influence of client feedback, Journal of Property Research, 17 (1): 47-58.

Gaver, J. J., and Paterson, J. S. (2007), The influence of large clients on office-level auditor oversight: Evidence from the property-casualty insurance industry. Journal of Accounting and Economics, 43 (2-3): 299-320.

Geltner, D., MacGregor, B. D. and Schwann, G. M. (2003), Appraisal Smoothing and Price Discovery in Real Estate Markets, Urban Studies, 40 (5/6): 1047-1064.

Griffin, J. and Tang, D. (2011), Did credit rating agencies make unbiased assumptions on CDOs? The American Economic Review, 101 (3): 125-130.

The final publication is available at Springer via http://dx.doi.org/10.1007/s10551-015-2953-1 
Habinek, J., Goldstein, A. and Fligstein, N. (2012), A field-theoretic approach to the transformation of subprime lending, 1993-2008. Working Paper. University of California, Berkeley.

Hansz, J. (2004), The use of a pending mortgage reference point in valuation judgement. Journal of Property Investment and Finance, 22 (3): 259-268.

Hansz, J. A. and Diaz III, J. (2001), Valuation Bias in Commercial Appraisal: A Transaction Price Feedback Experiment. Real Estate Economics, 29 (4): 553-565.

IPD (2014), Indexes and Benchmark Methodology Guide - June 2014. Investment Property Databank, London.

IPD (2015), IPD UK Quarterly Property Index: Results for the quarter to 31 December 2014, Investment Property Databank, London.

IPE Real Estate (2009), Special focus - valuations. IPE Real Estate, January-February, 28-31.

Khurana, I. and Raman, K. (2006), Do Investors Care about the Auditor's Economic Dependence on the Client? Contemporary Accounting Research, 23 (4): 977-1016.

Kinnard, W. N., Lenk, M. M. and Worzala, E. M. (1997), Client pressure in the commercial appraisal industry: how prevalent is it? Journal of Property Valuation and Investment, 15 (3): 233-244.

Lee, J. and Zhaoyang, G. (1998), Low balling, legal liability and auditor independence, Accounting Review, 73 (4): 533-556.

Levy, D. and Schuck, E. (1999), The influence of clients on valuations, Journal of Property Investment and Finance, 17 (4), 380-400.

Levy, D. and Schuck, E. (2005), The influence of clients on valuations: the client's perspective, Journal of Property Investment and Finance, 23 (2), 182-201.

The final publication is available at Springer via http://dx.doi.org/10.1007/s10551-015-2953-1 
Lin, H. and McNichols, M. (1998), Underwriting Relationships, Analysts' Earnings Forecasts and Investment Recommendations. Journal of Accounting and Economics, 25 (1): 101127.

Lizieri, C., Reinert, J. and Baum, A. (2011). Who Owns the City 2011: Change and Global Ownership of City of London Offices, Department of Land Economy, University of Cambridge.

Malmendier U. and Shantikumar, D. (2005), Are Investors Nä̈ve about Incentives? NBER Working Paper No. 10812.

McAllister, P., Baum, A., Crosby, N., Gallimore, P. and Gray, A. (2003), Appraiser behaviour and appraisal smoothing: some qualitative and quantitative evidence, Journal of Property Research, 20 (3): 261-280.

Michaely, R. and Womack, K. (1999), Conflict of Interest and the Credibility of Underwriter Analyst Recommendations. The Review of Financial Studies, 12 (4): 653-686.

Mitchell, P. (2014), The Size and Structure of the UK Property Market 2013: A Decade of Change. Investment Property Forum, London.

Nwuba, C. C., Egwuatu, U. S. and Salawu, B. M. (2015), Client influence on valuation: valuers' motives to succumb. Journal of Property Research, 32 (2): 147-172.

Quan, D. and Quigley, J. (1991), Price formation and the appraisal function in real estate markets, Journal of Real Estate Finance and Economics, 4 (2): 127-146.

Reynolds, J. K. and Francis, J. R. (2000), Does size matter? The influence of large clients on office-level auditor reporting decisions, Journal of Accounting and Economics, 30 (3): $375-400$.

The final publication is available at Springer via http://dx.doi.org/10.1007/s10551-015-2953-1 
RICS/IPD (2013), RICS IPD Valuation and Sale Price Report UK 2012. RICS/Investment Property Databank, London.

Rosen, S. (1974), Hedonic Prices and Implicit Markets: Product Differentiation in Pure Competition, The Journal of Political Economy, 82 (1): 34-55.

Royal Institution of Chartered Surveyors (RICS) (2002), Property Valuation: The Carsberg Report, Royal Institution of Chartered Surveyors, London.

Royal Institution of Chartered Surveyors (RICS) (2014), RICS Valuation - Professional Standards January 2014, Royal Institution of Chartered Surveyors, London.

Schein, E. (1984), Coming to a new awareness of organizational culture, Sloan Management Review, 25 (2): 3-16.

Smolen, G. and Hambleton, D. (1997), Is the real estate appraiser's role too much to expect? The Appraisal Journal, 65 (1): 9-17.

Teuben, B. and Clacy-Jones, M. (2015), Real Estate Market Size 2014: Insights into the size of the professionally managed global real estate market, MSCI, London.

Trevino, L. K. (1986), Ethical Decision Making in Organizations: A Person Situation Interactionist Model, The Academy of Management Review, 11 (3): 601-617.

Windsor, C. and Ashkansay, N. (1995), The effect of client management bargaining power, moral reasoning development and belief in audit, Accounting, Organizations \& Society, 20 (7-8): 701-21

Worzala, E. M., Lenk, M. M. and Kinnard, W. N. (1998), How client pressure affects the appraisal of residential property, The Appraisal Journal, 66 (4): 416-427.

Yu, S. (2002), Client pressure in residential valuations - evidence from Singapore, mimeo, Department of Real Estate, National University of Singapore

The final publication is available at Springer via http://dx.doi.org/10.1007/s10551-015-2953-1 
Zhang, P. (1999), A Bargaining Model of Auditor Reporting, Contemporary Accounting Research, 16 (1): 167-185.

Zimbelman, M. and Waller, W. (1999), An experimental investigation of auditor-auditee interaction under ambiguity. Journal of Accounting Research, 37: 135-156. 
Figure 1: The Determinants of Client Influence on Appraisals: A Conceptual Model

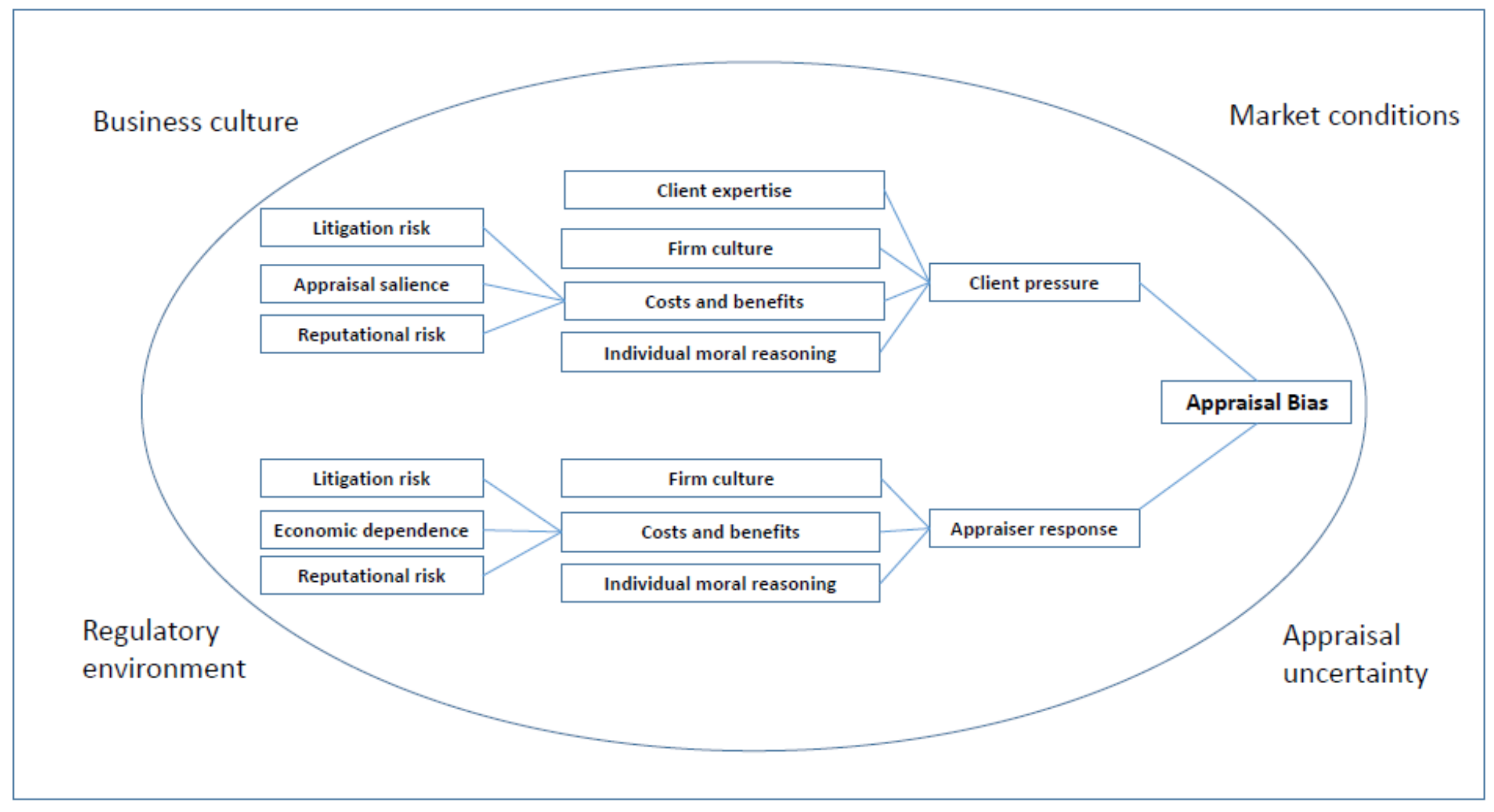

The final publication is available at Springer via http://dx.doi.org/10.1007/s10551-015-2953-1 
Figure 2: UK Commercial Real Estate Capital Growth Index, 2002-2012

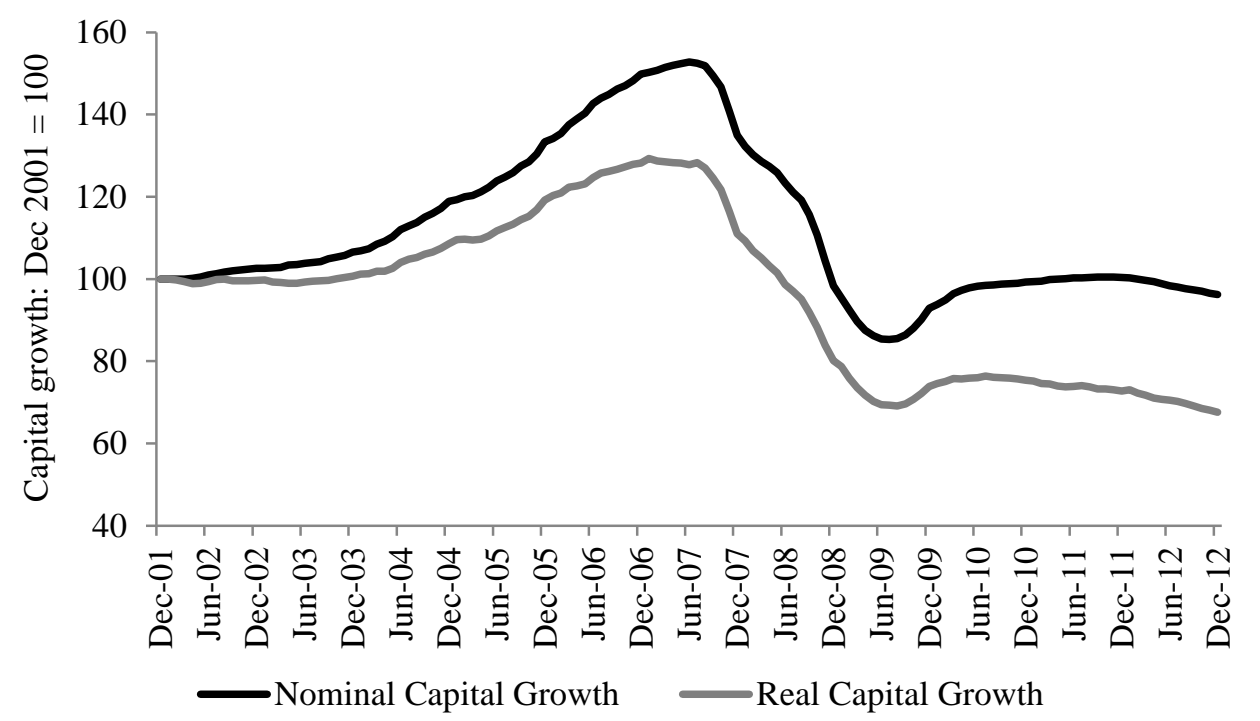

Source: Investment Property Databank UK Monthly Index (rebased) 
Table 1: Sample size by owner type and period

\begin{tabular}{lrrrrrrrrr}
\hline & $\mathrm{Q} 2$ & $\mathrm{Q} 3$ & $\mathrm{Q} 4$ & $\mathrm{Q} 1$ & $\mathrm{Q} 2$ & $\mathrm{Q} 3$ & $\mathrm{Q} 4$ & $\mathrm{Q} 1$ & $\mathrm{Q} 2$ \\
& 2007 & 2007 & 2007 & 2008 & 2008 & 2008 & 2008 & 2009 & 2009 \\
\hline Insurance companies & 723 & 713 & 686 & 660 & 644 & 631 & 620 & 612 & 604 \\
Pension funds & 1,569 & 1,589 & 1,489 & 1,488 & 1,488 & 1,405 & 1,397 & 1,376 & 1,366 \\
Unit linked funds & 2,144 & 2,230 & 1,773 & 1,609 & 1,512 & 1,231 & 1,043 & 1,089 & 1,006 \\
Open ended funds & 2,755 & 2,814 & 2,659 & 2,440 & 2,403 & 2,268 & 2,180 & 2,173 & 2,117 \\
Listed property & & & & & & & & & \\
companies \& REITs & 636 & 676 & 664 & 598 & 579 & 565 & 547 & 470 & 447 \\
Closed end funds & 269 & 261 & 258 & 222 & 219 & 220 & 219 & 146 & 149 \\
Other & 427 & 335 & 325 & 319 & 310 & 302 & 302 & 304 & 297 \\
\hline Total & 8,523 & 8,618 & 7,854 & 7,336 & 7,155 & 6,622 & 6,308 & 6,170 & 5,986 \\
\hline
\end{tabular}


Table 2: The Determinants of Asset Investment Performance in Quarter 4, 2007

\begin{tabular}{|c|c|c|c|}
\hline \multirow[b]{2}{*}{ Independent variables } & \multicolumn{3}{|c|}{$\begin{array}{l}\text { Dependent } \\
\text { Variables }\end{array}$} \\
\hline & $\begin{array}{l}\text { Capital } \\
\text { Growth }\end{array}$ & $\begin{array}{l}\text { Rental } \\
\text { Growth }\end{array}$ & $\begin{array}{c}\text { Yield } \\
\text { Impact }\end{array}$ \\
\hline Segment capital growth & $0.841^{* * * *}$ & $0.986^{* * * *}$ & $0.933^{* * * *}$ \\
\hline (Log) Capital value & $-0.477^{* * * *}$ & 0.026 & $-0.351^{* * * *}$ \\
\hline Excess yield (+) & $1.254^{* * *}$ & $-0.098^{* * *}$ & $1.733^{* * * *}$ \\
\hline Excess yield (-) & 0.060 & 0.037 & 0.229 \\
\hline Sold next quarter & $-1.713^{* *}$ & -0.240 & $-1.597^{* * *}$ \\
\hline Insurance company & Hold-out & Hold-out & Hold-out \\
\hline Pension fund & -0.089 & 0.019 & 0.092 \\
\hline Unit-linked fund & $-1.073^{* *}$ & -0.032 & $-0.788^{*}$ \\
\hline Open-ended fund & $-1.075^{* *}$ & -0.131 & $-0.818^{*}$ \\
\hline Listed property co & 0.827 & -0.014 & 1.046 \\
\hline Closed-end fund & $1.921^{*}$ & 0.466 & $1.818^{*}$ \\
\hline Other owner type & -0.379 & -0.016 & -0.223 \\
\hline Constant & $6.691^{* * * *}$ & -0.388 & $4.923^{* * * *}$ \\
\hline Adjusted $R^{2}$ & 0.201 & 0.051 & 0.202 \\
\hline F-statistic & 22.58 & 15.39 & 26.84 \\
\hline Probability $F=0$ & 0.000 & 0.000 & 0.000 \\
\hline No of observations & 7,849 & 7,849 & 7,849 \\
\hline
\end{tabular}

The final publication is available at Springer via http://dx.doi.org/10.1007/s10551-015-2953-1 
Table 3: Movements Associated with Type of Owner in Cases where Coefficients are Statistically Significant

\begin{tabular}{|c|c|c|c|c|c|c|c|c|}
\hline & 2007Q3 & 2007Q4 & 2008Q1 & 2008Q2 & 2008Q3 & 2008Q4 & 2009Q1 & 2009Q2 \\
\hline \multicolumn{9}{|l|}{ Capital growth } \\
\hline Unit-linked fund & + & - & & & & & - & \\
\hline Open-ended fund & & - & & & - & & & \\
\hline Closed-end fund & & + & + & & & & & \\
\hline \multicolumn{9}{|l|}{ Yield impact } \\
\hline Unit-linked fund & + & - & & & & & & \\
\hline Open-ended fund & & - & & & & & & \\
\hline Closed-end fund & & + & + & & & & & \\
\hline
\end{tabular}


Appendix Table A1: Capital growth regression results

\begin{tabular}{|c|c|c|c|c|c|c|c|c|}
\hline & Quarter & Quarter & Quarter & Quarter & Quarter & Quarter & Quarter & Quarter \\
\hline & 2007Q3 & 2007Q4 & 2008Q1 & 2008Q2 & 2008Q3 & 2008Q4 & 2009Q1 & 2009Q2 \\
\hline Segment capital growth & $0.876^{* * * *}$ & $0.841^{* * * *}$ & $0.753^{* * * *}$ & $0.794^{* * *}$ & $0.661^{* * *}$ & $0.871^{* * *}$ & $0.643^{* * *}$ & $1.023^{* * * *}$ \\
\hline Ln capital value ${ }^{1}$ & $0.144^{* *}$ & $-0.477^{* * *}$ & -0.062 & $-0.154^{* *}$ & $-0.209^{* * *}$ & $-0.753^{* * *}$ & $-0.554^{* * *}$ & $-0.203^{* *}$ \\
\hline Excess yield $(+)^{1}$ & $0.866^{* * *}$ & $1.254^{* * *}$ & $0.699^{* * *}$ & $0.505^{* * *}$ & $0.591^{* *}$ & 0.076 & -0.256 & $-0.493^{*}$ \\
\hline Excess yield (-) ${ }^{1}$ & $-0.857^{* * *}$ & 0.060 & -0.139 & $-0.820^{* * *}$ & $-1.674^{* * *}$ & $-2.105^{* * *}$ & $-2.441^{* * * *}$ & $-1.692^{* * * *}$ \\
\hline Sold next quarter & -0.093 & $-1.713^{* *}$ & 0.496 & -0.168 & -0.792 & $-2.297^{* *}$ & -0.567 & $1.816^{* * *}$ \\
\hline Insurance company & Hold-out & Hold-out & Hold-out & Hold-out & Hold-out & Hold-out & Hold-out & Hold-out \\
\hline Pension fund & $-0.846^{* * *}$ & -0.089 & 0.254 & $-0.680^{* *}$ & -0.368 & -0.075 & $-0.834^{* * *}$ & 0.194 \\
\hline Unit-linked fund & $0.583^{* *}$ & $-1.073^{* *}$ & -0.374 & 0.038 & -0.608 & 0.276 & $-0.987^{* *}$ & 0.148 \\
\hline Open-ended fund & 0.023 & $-1.075^{* *}$ & 0.465 & -0.359 & $-0.538^{*}$ & 0.440 & -0.395 & -0.170 \\
\hline Listed property co & $-0.603^{*}$ & 0.827 & 0.369 & -0.424 & -0.314 & 1.208 & -0.424 & 0.290 \\
\hline Closed-end fund & 0.937 & $1.921^{*}$ & $2.162^{* * * *}$ & -0.454 & 0.430 & 0.537 & 0.438 & -0.576 \\
\hline Other owner type & -0.273 & -0.379 & -0.248 & -0.304 & 0.081 & 0.336 & -0.166 & 0.057 \\
\hline Constant & $-3.408^{* * * *}$ & $6.691^{* * *}$ & -0.746 & $1.786^{*}$ & 1.034 & $9.623^{* * *}$ & $6.029^{* * *}$ & $2.833^{*}$ \\
\hline Adjusted $R^{2}$ & 0.158 & 0.201 & 0.070 & 0.071 & 0.045 & 0.113 & 0.089 & 0.092 \\
\hline F-statistic & 22.65 & 22.58 & 36.95 & 19.77 & 14.40 & 22.21 & 35.28 & 37.59 \\
\hline Probability $F=0$ & 0.000 & 0.000 & 0.000 & 0.000 & 0.000 & 0.000 & 0.000 & 0.000 \\
\hline No of observations & 8613 & 7849 & 7331 & 7148 & 6612 & 6308 & 6169 & 5986 \\
\hline
\end{tabular}

$t$ statistics in parentheses, ${ }^{*} p<0.10,{ }^{* *} p<0.05,{ }^{* * *} p<0.01$

${ }^{1}$ These control variables are measured as at Q2 2007 in each case.

The final publication is available at Springer via http://dx.doi.org/10.1007/s10551-015-2953-1 
Appendix Table A2: Rental value growth regression results

\begin{tabular}{|c|c|c|c|c|c|c|c|c|}
\hline & Quarter & Quarter & Quarter & Quarter & Quarter & Quarter & Quarter & Quarter \\
\hline & 2007Q3 & 2007Q4 & 2008Q1 & 2008Q2 & 2008Q3 & 2008Q4 & 2009Q1 & 2009Q2 \\
\hline Segment rental growth & $0.658^{* * *}$ & $0.986^{* * *}$ & $0.636^{* * * *}$ & $0.565^{* * *}$ & $0.638^{* * *}$ & $0.819^{* * *}$ & $0.813^{* * *}$ & $0.950^{* * * *}$ \\
\hline Ln capital value $^{1}$ & 0.036 & 0.026 & -0.007 & -0.013 & $-0.111^{* * * *}$ & $-0.159^{* * * *}$ & $-0.194^{* * * *}$ & $-0.153^{* *}$ \\
\hline Excess yield $(+)^{1}$ & 0.051 & $-0.098^{* *}$ & -0.062 & -0.046 & -0.040 & $-0.249^{* *}$ & 0.059 & -0.066 \\
\hline Excess yield (-) ${ }^{1}$ & -0.140 & 0.037 & $-0.193^{*}$ & -0.116 & $-0.166^{*}$ & -0.241 & $-0.423^{* *}$ & $-0.435^{* *}$ \\
\hline Sold next quarter & $-0.417^{* * *}$ & -0.240 & 0.004 & 0.091 & -0.043 & -0.020 & 0.027 & 0.220 \\
\hline Insurance company & Hold-out & Hold-out & Hold-out & Hold-out & Hold-out & Hold-out & Hold-out & Hold-out \\
\hline Pension fund & -0.006 & 0.019 & -0.044 & -0.143 & -0.019 & -0.033 & 0.009 & 0.130 \\
\hline Unit-linked fund & 0.096 & -0.032 & -0.065 & -0.080 & -0.140 & 0.033 & 0.161 & 0.268 \\
\hline Open-ended fund & 0.093 & -0.131 & -0.138 & -0.075 & -0.078 & -0.027 & -0.083 & 0.342 \\
\hline Listed property co & 0.047 & -0.014 & -0.150 & -0.137 & -0.009 & 0.566 & 0.482 & $0.551^{*}$ \\
\hline Closed-end fund & 0.209 & 0.466 & 0.241 & 0.049 & $0.477^{* *}$ & $0.514^{* * *}$ & 0.637 & 0.313 \\
\hline Other owner type & 0.061 & -0.016 & -0.153 & -0.118 & -0.062 & 0.136 & 0.543 & 0.590 \\
\hline Constant & -0.556 & -0.388 & 0.277 & 0.400 & $1.882^{* * *}$ & $2.471^{* * *}$ & $2.650^{* * * *}$ & $2.026^{*}$ \\
\hline Adjusted $R^{2}$ & 0.117 & 0.051 & 0.014 & 0.017 & 0.025 & 0.202 & 0.188 & 0.112 \\
\hline F-statistic & 31.99 & 15.39 & 4.70 & 4.94 & 9.21 & 44.71 & 39.11 & 34.32 \\
\hline Probability $\mathrm{F}=0$ & 0.000 & 0.000 & 0.000 & 0.000 & 0.000 & 0.000 & 0.000 & 0.000 \\
\hline No of observations & 8613 & 7849 & 7331 & 7148 & 6612 & 6308 & 6169 & 5986 \\
\hline
\end{tabular}

$t$ statistics in parentheses, ${ }^{*} p<0.10,{ }^{* *} p<0.05,{ }^{* * *} p<0.01$

${ }^{1}$ These control variables are measured as at Q2 2007 in each case.

The final publication is available at Springer via http://dx.doi.org/10.1007/s10551-015-2953-1 
Appendix Table A3: Yield impact regression results

\begin{tabular}{|c|c|c|c|c|c|c|c|c|}
\hline & Quarter & Quarter & Quarter & Quarter & Quarter & Quarter & Quarter & Quarter \\
\hline & 2007Q3 & 2007Q4 & 2008Q1 & 2008Q2 & 2008Q3 & 2008Q4 & 2009Q1 & 2009Q2 \\
\hline Segment yield impact & $0.777^{* * *}$ & $0.933^{* * *}$ & $0.546^{* * * *}$ & $0.957^{* * *}$ & $0.707^{* *}$ & $0.918^{* * *}$ & $0.778^{* * * *}$ & $1.077^{* * * *}$ \\
\hline Ln capital value ${ }^{1}$ & $0.239^{* * *}$ & $-0.351^{* * *}$ & 0.0534 & -0.132 & -0.0624 & $-0.482^{* * *}$ & $-0.241^{* *}$ & $-0.202^{* *}$ \\
\hline Excess yield $(+)^{1}$ & $1.145^{* * *}$ & $1.733^{* * * *}$ & $0.973^{* * *}$ & $0.632^{* * *}$ & $0.809^{* * *}$ & $0.342^{* *}$ & 0.246 & -0.170 \\
\hline Excess yield (-) ${ }^{1}$ & $-0.518^{* *}$ & 0.229 & 0.255 & $-0.684^{* * * *}$ & $-1.428^{* * *}$ & $-1.553^{* * *}$ & $-2.017^{* * *}$ & $-1.146^{* * * *}$ \\
\hline Sold next quarter & 0.132 & $-1.597^{* *}$ & $0.745^{*}$ & $-1.381^{* * * *}$ & $-1.975^{* * *}$ & $-2.103^{*}$ & -0.694 & 0.877 \\
\hline Insurance company & Hold-out & Hold-out & Hold-out & Hold-out & Hold-out & Hold-out & Hold-out & Hold-out \\
\hline Pension fund & $-0.769^{* *}$ & 0.0916 & 0.266 & -0.413 & -0.104 & 0.200 & -0.440 & 0.168 \\
\hline Unit-linked fund & $0.553^{*}$ & $-0.788^{*}$ & -0.496 & 0.232 & -0.253 & 0.486 & -0.600 & 0.147 \\
\hline Open-ended fund & 0.0606 & $-0.818^{*}$ & 0.405 & -0.245 & -0.315 & 0.588 & -0.191 & -0.192 \\
\hline Listed property co & -0.203 & 1.046 & $0.809^{*}$ & -0.547 & -0.267 & 1.286 & -0.425 & -0.822 \\
\hline Closed-end fund & 0.863 & $1.818^{*}$ & $1.943^{* * * *}$ & -0.421 & 0.0418 & 0.201 & 0.470 & -1.287 \\
\hline Other owner type & -0.299 & -0.223 & -0.194 & -0.159 & 0.326 & 0.417 & 0.0443 & -0.0722 \\
\hline Constant & $-5.439^{* * *}$ & $4.923^{* * *}$ & $-3.814^{*}$ & 1.813 & -1.345 & $5.573^{* * *}$ & 2.014 & $3.227^{* *}$ \\
\hline Adjusted $R^{2}$ & 0.112 & 0.202 & 0.060 & 0.049 & 0.033 & 0.096 & 0.077 & 0.062 \\
\hline F-statistic & 20.49 & 26.84 & 24.43 & 15.02 & 8.69 & 18.53 & 31.91 & 16.32 \\
\hline Probability $F=0$ & 0.000 & 0.000 & 0.000 & 0.000 & 0.000 & 0.000 & 0.000 & 0.000 \\
\hline No of observations & 8613 & 7849 & 7331 & 7148 & 6612 & 6308 & 6169 & 5986 \\
\hline
\end{tabular}

$t$ statistics in parentheses, ${ }^{*} p<0.10,{ }^{* *} p<0.05,{ }^{* * *} p<0.01$

${ }^{1}$ These control variables are measured as at Q2 2007 in each case.

The final publication is available at Springer via http://dx.doi.org/10.1007/s10551-015-2953-1 